Recenzje / Reviews

\author{
Sergio Liaszenko \\ ORCID: 0000-0002-1897-3252 \\ s126@stud.uph.edu.pl
}

Uniwersytet Przyrodniczo-Humanistyczny w Siedlcach

Wydział Nauk Społecznych

\title{
Nagorno-Karabakh Conflict \\ 30-летие конфликта в Нагорном Карабахе. Сборник научнъх статей, ред. Константин Петрович Курымев, Российский университет дружбы народов, Москва 2019, сс. 172
}

[30 years of Conflict in Nagorno-Karabakh. Collection of scientific articles, ed. Konstantin Petrovich Kurylev, People's Friendship

University of Russia, Moscow 2019, 172 p.]

DOI: $10.34739 /$ doc.2020.17.20

One of the most unsettled conflicts on the territory of postSoviet Union countries is that of Nagorno-Karabakh. The conflict is deeply rooted in history and the perspectives of its resolution seem to be uncertain ${ }^{1}$. Armenia and Azerbaijan have been trying to come to agreement since the 1990s, however, the main issues of the conflict have not been solved yet due to the completely different views of both states: Armenia wants to protect the right of its nation for selfdetermination, whereas Azerbaijan would like to preserve the territorial integrity of the country. The conflict between the two countries

\footnotetext{
${ }^{1}$ More information on the conflict background can be found in the following publications: P. Adamczewski, Górski Karabach w polityce niepodległego Azerbejdżanu, Warszawa 2012; A. Chodubski, Górski Karabach: odsłony sporów i walk, [in:] Armenia. Dziedzictwo a współczesne kierunki przemian kulturowo-cywilizacyjnych, ed. P. Nieczuja-Ostrowski, Poznań 2016, pp. 225-240; K. Stasiak, W.Sz. Staszewski, A. Szarek-Zwijacz, Stosunki polsko-armeńskie. Wybór dokumentów z wprowadzeniem, Lublin 2017, pp. 14-20; T. Grzywaczewski, Granice marzeń. O państwach nieuznawanych, Wołowiec 2018.
} 
escalated in July 2020. Armenia and Azerbaijan put forward mutual accusations of violating the ceasefire. According to the recent statement of the President of Azerbaijan Ilham Aliyev, the negotiations within the framework of OSCE Minsk Group between Armenia and Azerbaijan have been conducted for about 30 years without success and in the last few years they turned out to be pointless ${ }^{2}$.

Taking into consideration the above mentioned points there is a constant need to collect new facts and opinions on the subject of the Nagorno-Karabakh conflict and keep them up-to-date in order to look for new and better solutions to the problem. Therefore, the latest collection of articles titled 30 years of Conflict in Nagorno-Karabakh edited by A.P. Kurylev is an attempt to fill the gap on this topic. The publication provides different views of scientists and students from different countries and of different age groups at different stages of study.

The collection of articles was compiled as a result of the International Scientific Round Table Debate which took place in People's Friendship University of Russia (RUDN University) at the Faculty of Humanities and Social Sciences on 14th December 2018. The articles were prepared by the representatives of RUDN University studying the problems of the post-Soviet space as well as leading specialists and experts from the Republic of Azerbaijan (Baku State University), the Republic of Armenia (Yerevan State University), MGIMO University (Moscow State Institute of International Relations), Diplomatic Academy of the Ministry of Foreign Affairs of the Russian Federation. The authors include Denis A. Degterev, Vladimir A. Tsvyk, Sergey M. Markedonov, Vaagn R. Aglyan, Konstantin P. Kurulev, Alimusa Gyulmusa Ibragimov, Dmitriy A. Sidorov, Mirmekhti Mirkamil ogly Agazade, Ovannes Gevorkyan, Nuride Guseynova, Aytadj Alovset kyzy Gasanova, Anastasiya R. Andronova, Arina D. Sharavina, Larisa S. Kolesnikova, Polina M. Pavlova, Yekaterina A. Penkova, Yulia P. Gnusova, Olga K. Maximova, Roman A. Adlov, Andrey E. Marchenko.

2 Ю. Выродова, Алиев назвал бессмысленными переговоры с Арменией в последние годы, РБК 01.01.2021, https://www.rbc.ru/politics/01/01/2021/ 5feec9919a79473698da7b2b, (дата доступа: 30.12.2020). 
The book contains 172 pages and includes 16 articles concerning various aspects of the Nagorno-Karabakh conflict starting from its origin, perspectives of its resolution, its influence on the foreign policy of Armenia and Azerbaijan as well as the external factors influencing the resolution of the conflict and the impact it has on the post-Soviet space. All the articles are written in Russian, which is a big advantage since it considerably expands the target audience of the book giving it a chance to be understood by readers from both countries involved in the conflict as well as by representatives of international society. The structure of the book is clear and easy to follow.

The opening article written by D.A. Degterev and V.A. Tsvyk gives an overall view on international conflicts in different parts of the world analyzing how the study of their background and mechanisms of their resolution can be applied on the territory of post-Soviet states ${ }^{3}$. It lists the leading specialists and experts whose vision of the problem of conflicts is valued in the scientific world and mentions the most important periodicals which have published their studies. There is also an explanation why the conflict of NagornoKarabakh is worth being paid attention to and which factors influence the situation in the region.

Several articles deal with the attitude of different countries towards the conflict in Nagorno-Karabakh including Russia, the USA, Ukraine, Iran, France, China as well as the European Union. The leading part in the process of negotiations between Armenia and Azerbaijan unquestionably belongs to Russia as it inherited the role of the leader after the collapse of the Soviet Union. This issue is touched upon in the article by S.M. Markedonov ${ }^{4}$. It reveals how the conflict became one of the factors which led to the collapse of the USSR and afterwards determined the interests the Russian Federation pursued in the process of stabilizing the situation in the region. The aims and motives of Russia's involvement in peaceful regulation of the conflict are explained further on. The author also mentions

3 Д.А. Дегтерев, В.А. Цвык, Анализ конфликтов на постсоветском пространстве: исследования РУДН, [in:] 30-летие конфликта в Нагорном Карабахе. Сборник научных статей, еd. К.П. Курылев, Москва 2019, рр. 3-10.

4 C.М. Маркедонов, Россия в проиессе Нагорно-Карабахского урегулирования, [in:] ibidem, pp. 11-26. 
similarities and differences of the Nagorno-Karabakh conflict with the other post-Soviet conflicts in Georgia, Ukraine and Moldova as well as the influence the conflict has on the relations and cooperation with other countries - the USA, Iran, Turkey and the EU.

The article by V.R. Aglyan explains the reasons why the USA got so deeply and directly involved in the process of pacifying the conflict $^{5}$. The potential danger that the issue might become international involving neighbouring countries, first of all Turkey which is a member of NATO, encouraged Washington to take an active politicodiplomatic part in regional affairs. NATO's southern flank destabilization in case of Turkey's military involvement in the conflict might become a serious problem for the USA. Furthermore, the article points out the significant role Russia plays in resolving the conflict showing great interest in peaceful regulation of the issue.

In his article K.P. Kurylev pays attention to one of the factors which influence Ukraine's foreign policy concerning the NagornoKarabakh conflict, which is the ethnic-confessional situation in the country ${ }^{6}$. The conflict has created conditions for the growth of Armenian and Azerbaijani population in Ukraine, thus enabling the formation of some of the largest ethnical diasporas on the territory of the country. On the other hand, Ukraine's economic interests in diversifying energy resources are closely connected with the situation in Transcaucasian region since the official Kyiv is interested in keeping good trade relations with Azerbaijan as well as with Turkmenistan, Kazakhstan and Iran. However, the key factor defining Ukraine's policy concerning Nagorno-Karabakh is the relationship between Kyiv and Moscow.

The attitude of Iran towards the countries involved in the Nagorno-Karabakh conflict is quite surprising. As M.M. Agazade states in his article, Iran, being an Islamic state, openly stands for keeping the territorial integrity of Azerbaijan and, at the same time, according

5 В.Р. Аглян, Мозговые иентры и экспертное сообшество США о Карабахском конфрликте и роли РФ, [in:] ibidem, pp. 27-39.

6 К.П. Курылев, Факторы, определявшие внешнюю политику Украины по вопросу Нагорно-Карабахского урегулирования (1992-1994 гг.), [in:] ibidem, pp. 40-51. 
to some views, silently supports Armenia7. Thus, the fact that the conflict still remains unsettled is, in a certain way, quite a satisfactory situation for Iran.

The position of China (standing for peaceful regulation of the conflict) is revealed in the articles by Ye.A. Penkova, Yu.P. Gnusova and O.K. Maximova ${ }^{8}$. China mainly shows interest in economic and commercial relations with the countries of the region emphasizing the significance of solely peaceful resolution of the conflict between Armenia and Azerbaijan giving absolutely no comments as to either the territorial integrity of states or the right of nations for self-determination. Special attention is paid to the issue of Nagorno-Karabakh by the European Union, especially France, which is described in the articles by L.S. Kolesnikova and P.M. Pavlova9. In fact, the EU generally assists and supports the actions of OSCE Minsk Group and UNO with France playing the role of the leader.

R.A Adlov and A.E. Marchenko focus their attention on religious factors ${ }^{10}$. Islam is an important part of life in Islamic countries and considerably influences their foreign policy. Unfortunately, no attention is paid in the article in question to the significance of the main religion of Armenia - Orthodox Christianity. The religious factor, being an essential component of cultural and civilizational identity of both countries in conflict - Armenia and Azerbaijan, played a substantial role in the relations between the countries. This issue is given a detailed perspective in the article by R. Król-Mazur in another publication about Armenia ${ }^{11}$.

\footnotetext{
7 М.М. Агазаде, Позииия Ирана по Нагорно-Карабахскому Конфликту, [in:] ibidem, pp. 62-69.

8 Е.А. Пенькова, Ю.П. Гнусова, Подходъ КНР $\kappa$ конфрликту в Нагорном Kapaбaxe, [in:] ibidem, pp. 105-113; О.К. Максимова, Е.А. Пенькова, ПекинБаку: взгляд на отношения с ретроспективой, [in:] ibidem, pp. 114-126.

9 М.С. Колесникова, Роль европейского союза в Нагорно-Карабахском конфликте, [in:] ibidem, pp. 86-96; П.М. Павлова, Роль Франиии в урегулировании Нагорно-Карабахского конфликта, [in:] ibidem, pp. 97-104. 10 Р.А. Адмов, А.Е. Марченко, Фактор исламской солидарности в Нагорном Kapaбaxe, [in:] ibidem, pp. 127-138.

11 R. Król-Mazur, Rola religii w konflikcie o Górski Karabach, [in:] Armenia. Dziedzictwo a wspótczesne kierunki przemian kulturowo-cywilizacyjnych, ed. P. Nieczuja-Ostrowski, Poznań 2016, p. 241.
} 
Other important issues influencing the situation in Nagorno-Karabakh are also touched upon in this collection of articles. The general principles and evolution of foreign policy of both Armenia and Azerbaijan are paid attention to in the articles by O. Gevorkyan and N. Guseynova ${ }^{12}$; A.R. Andronova and A.D. Sharavina take a closer look at the role of international intergovernmental organizations ${ }^{13}$; A.G. Ibragimov explains the importance of regional integration ${ }^{14}$; D.A. Sidorov takes an attempt to find out if any changes occurred in the Nagorno-Karabakh issue after the Velvet Revolution in Armenia15; the role of diaspora in Russian-Azerbaijani relations is studied by A.A. Gasanova ${ }^{16}$.

The above mentioned articles prove that the publication 30 Years of Conflict in Nagorno-Karabakh edited by A.P. Kurylev presents a valuable study of many specialists and experts as well as young scholars studying the problems of the Nagorno-Karabakh conflict. It will unquestionably be useful for everyone who wants to expand their knowledge on the matter - not only for specialists who deal with foreign policy of post-Soviet countries, conflictology and international relations, but also for those who specialize in national security, diplomatic relations as well as the history of the Transcaucasian region. This compilation is also worth paying attention to due to the fact that it is one of the latest works on the conflict published in recent years. That is why it will undoubtedly be of great value for a potential reader.

12 О. Геворкян, Эволюиия внешней политики Армении, Н. Гусейнова, Приниипь и приоритеты внешнеполитической деятельности Азербайджанской Республики, [in:] ibidem, pp. 139-162.

13 А.Р. Андронова, А.Д. Шаравина, Роль международных межправительственных организаиий в урегулировании конфликта в Нагорном Карабахе, [in:] ibidem, pp. 70-85.

14 А.Г. Ибрагимов, Нагорный Карабах - разрешение конфликта посредством региональной интеграйи, [in:] ibidem, pp. 52-56.

15 Д.А. Сидоров, Нагорно-Карабахский конорликт после бархатной революиии в Армении, [in:] ibidem, pp. 57-61.

16 А.А. Гасанова, Роль диаспоры в российско-азербайджанских отношениях, [in:] ibidem, pp. 163-170. 


\section{References}

30-letie konflikta v Nagornom Karabahe. Sbornik naučnyh statej, red. K.P. Kurylev, Moskva 2019, [30-летие конфрликта в Нагорном Карабахе. Сборник научных статей, ред. К.П. Курылев, Москва 2019].

Adamczewski P., Górski Karabach w polityce niepodległego Azerbejdżanu, Warszawa 2012.

Chodubski A., Górski Karabach: odsłony sporów i walk, [in:] Armenia. Dziedzictwo a współczesne kierunki przemian kulturowo-cywilizacyjnych, ed. P. Nieczuja-Ostrowski, Poznań 2016.

Grzywaczewski T., Granice marzeń. O państwach nieuznawanych, Wolowiec 2018.

Król-Mazur R., Rola religii $w$ konflikcie o Górski Karabach, [in:] Armenia. Dziedzictwo a współczesne kierunki przemian kulturowo-cywilizacyjnych, ed. P. Nieczuja-Ostrowski, Poznań 2016.

Stasiak K., Staszewski W. Sz., Szarek-Zwijacz A., Stosunki polsko-armeńskie. Wybór dokumentów z wprowadzeniem, Lublin 2017.

Vyrodova U., Aliev nazval bessmyslennymi peregovory s Armeniej v poslednie gody, RBK 01.01.2021, https://www.rbc.ru/politics/ 01/01/2021/5feec9919a79473698da7b2b, (data dostupa: 30.12.2020), [Выродова Ю., Алиев назвал бессмысленными переговоры с Арменией в последние годы, РБК 01.01.2021, https://www.rbc.ru/politics/01/01/2021/5feec9919a7947369 8da7b2b, (дата доступа: 30.12.2020)]. 
